\title{
Reforma do Aparelho Arrecadador do Ministério da Fazenda
}

\section{Paulo Coriolano Tunis Viana}

Completando pontos de vista expendidos em número anterior da R.S.P., a respeito de reformulações de organismos exatores do Ministério da Fazenda, o autor, Paulo Coriolano Tunis Viana, fornece-nos o que denomina "Anteprojeto de Lei, Sôbre Modificações no Aparelho Arrecadador do Ministério da Fazenda".

No mesmo anteprojeto, - que sintetiza e interpreta a opinião de nosso colaborador, - além das modificações em diversos órgãos exatores, com novas denominações e atribuições, é prevista a criação e zoneamento de 350 Coletorias Federais, cujas competências e atividades são também detalhadas.

O trabalho, dada a atualidade do assunto, face aos estudos que vêm sendo empreendidos, para a reforma administrativa do Pais, servirá, talvez, como subsidio aos mesmos estudos, trazendo argumentos e opiniões novas, ao debate do assunto. - (NOTA $D A$ REDAÇ $\tilde{O}$ ).

$\mathrm{C}$

ontinua em evidência o tema das reformas de base, dentre as quais se destaca a reforma administrativa, filiada à qual se avulta a do setor fazendário, dada a relevância com que se apresenta o ordenamento das finanças públicas perante os grandes problemas nacionais, alvo invariável para onde necessàriamente converge a atenção dos atuais responsáveis pelo destino do nosso país.

É oportuno, pois, que se dê divulgação a todo trabalho que possa contribuir de alguma maneira a ajudar aos nossos dirigentes a encontrarem a solução certa para essas momentosas questões, de que tanto dependem a prosperidade e a paz do povo brasileiro. 
Não é outro o propósito dêste despretensioso trabalho, consistente de esbôço de lei contendo medidas destinadas a melhorar o sistema arrecadador federal, acompanhado da respectiva justificação da matéria.

A sua elaboração resulta de estudos realizados, de algum tempo a esta parte, quer no exercício das funções de chefe da Seção de Orientação e Inspeção da Diretoria das Rendas Internas, quer como participante do Grupo de Trabalho criado por ato da Direção-Geral da Fazenda Nacional, para estudar o reaparelhamento das Coletorias Federais e a dinamização de seus ser. viços, trabalho êste que representa nãu sòmente os dados de minha experiência pessoal, colhidos no trato constante com os serviços atinentes à arrecadação das rendas da União, ou no conhecimento de tudo que as anteriores administrações fazendárias realizaram nesse campo, como também as observações, sugestões e estudos de distintos colegas de serviço, que igualmente dedicam seus esforços no melhoramento dêsse importante setor fazendário.

Não é ignorada, evidentemente, a existência atual de uma Comissão integrada por competentes técnicos pertencentes à Fundação Getúlio Vargas, incumbida pelo Govêrno Federal de elaborar a reforma do Ministério da Fazenda, nos têrmos da Lei $n^{2} 4.155$, de 1962 .

Igualmente conhecida é a opinião de alguns de seus mais destacados membros, no tocante à reestruturação do aparelho arrecadador federal, os quais defendem o ponto-de-vista de que, por ser mais econômico e por permitir solução mais imediata, deve ser definitivamente atribuida aos bancos particulares a função de arrecadar as rendas federais, como órgãos auxiliares das repartições arrecadadoras do Ministério da Fazenda, de modo a dinamizar a execução dêsses serviços, solução esta, aliás, já antecipada pela autorização constante da Portaria Ministerial número GB 431, publicada no Diário Oficial de 12 de dezembro de 1963.

Como tese aqui defendida é contrária a êste respeito, por entender-se que a função de arrecadar as rendas federais, por suas caracteristicas especiais, deve ser confiada, exclusivamente, a repartições fazendárias; e que o estendê-las a bancos particulares, sujeitos êles próprios às leis fiscais, implicará na criação de um sistema misto, cujo hibridismo só pode resultar em maiores perturbações aos serviços de arrecadação das rendas públicas, por forçar, ou melhor dizendo, por violentar a ordem legal existente - conforme já foi manifestado em comentário sôbre o assunto, publicado no número anterior desta Revista - o trabalho aqui apresentado, que preconiza a solução do problema através da reestruturação racional do aparelho arrecadador federal, traduz a 
objetivação dêste meu ponto-de-vista, ao mesmo tempo que mostra a viabilidade da reforma do sistema, sem precisar recorrer a medidas estranhas que usurpem as suas prerrogativas e deformem a sua verdadeira constituição.

Entrego ao alto descortinio das superiores autoridades que tiverem de decidir sôbre o assunto, o julgar do acêrto, oportunidade e conveniência do que se propõe neste trabalho.

Eis, na integra, o texto do esbôço e justificação, que submeto à crítica dos doutos e interessados no assunto:

\section{LEI $N$ DE DE 196}

Introduz modificação no aparelho artecadador do Ministério da Fazenda.

Art. $1^{\circ}$ Com base no sistema de pluralidade de exatorias situadas em centros demográficos em que o indice de arrecadação das rendas federais seja expressivo, admite-se a existência, em uma só localidade, de tantas estações arrecadado:as quantas forem necessárias à boa execução dos serviços.

Art. 2จ A instalação de Coletorias Federais, pela Administração da Fe. zenda Nacional, em localidades que comportem mais de uma exatoria, será precedida de divisão da localidade em zonas fiscais, cuja jurisdição será estabelecida segundo o número de habitantes e de estabelecimentos comerciais e industriais existentes.

Art. $3^{\circ}$ As Coletorias Federais de uma mesma localidade serão situadas em pontos centrais de fácil acesso, devendo guardar entre si distância razoável, a juizo da Administração da Fazenda Nacional, de modo a atender, satisfatòriamente, ao público contribuinte.

Art. $4^{\circ}$ Compete às Coletorias Fede:ais, com exclusividade, arrecadar os impostos internos devidos à Unnião, ou a cargo desta, assim compreendidos todos os tributos federais, excetuados os de importação e afins, cuja arrecadação é da competência das estações aduaneiras.

Art. 5 A Administração da Fazenda Nacional procederá, dentro do prazo de sessenta $(60)$ dias, ao levantamento das localidades sedes de Mesas de Rendas Alfandegadas, de expressivo indice de arrecadação de impostos internos, baseado no qual o Poder Executivo proporá ao Legislativo a criação de Coletorias Federais, para funcionarem nessas localidades.

Art. 6 Salvo os casos excepcionais, a Administração da Fazenda Nacional p:omoverá a anexação, à congênere mais próxima, de tôda Coletoria cuja arrecadação da receita orçamentária não atinja, em um exercício, valor igual a cinqüenta $(50)$ vêzes o mais elevado salário-minimo vigente no Pais.

Parágrafo único. Só poderá ser criada Coletoria em Municipios que assegurem, segundo levantamento de dados precisos, a renda igual ou superior à indicada neste artigo e que possuam mais de duzentos (200) contribuintes dos impostos de consumo e renda.

Art. $7^{\circ}$ São criadas trezentas e cinqüenta (350) Coletorias Federais, localizadas nos seguintes Municipios, assim distribuidas: Amazonas: três Co. letorias em Manaus; Pará: cinco em Belém: Maranhão: duas em São Luiz; Piaui: três em Terezina e duas em Parnaiba; Ceará: cinco em Fortaleza; Rio Grande do Norte: duas em Natal; Parába: três em João Pessoa e duas em Campina Grande; Pernambuco: dez em Recife, uma em Cabo, uma em 
Caruaru, uma em Pesqueira, uma em Garanhuns e uma em Igaraçu; Alagoas: três em Maceió; Sergipe: três em Aracaju; Bahia: dez em Salvador, uma em Maragogipe, uma em Feira de Santana, uma em Jaguaribe, duas em Ilhéus, duas cm Itabuna, uma em Santo Amaro e uma em Vitória da Conquista; Minas Gerais: dez em Belo Horizonte, três em Juiz de Fora, duas em Uberlândia, duas em Uberaba, uma em Ituiutaba, uma em Araguari, uma em Governador Valadares, uma em Teófilo Otônio, uma em Montes Claros, uma em Curvelo, uma em Poços de Caldas e uma em Ponte Nova; Espirito Santo: quatro em Vitória, uma em Cachoeiro do Itapemirim, uma em Mimoso do Sul; Rio de Janeiro: dez em Niterói, duas em Campos, uma em Nova Frı. burgo, duas em São Gonçalo, duas em Petrópolis, duas em Ncva Iguaçu, uma em Terezópolis, uma em Nilópolis, uma em Barra Mansa, uma em Volta Redonda, uma em Barra do Pirai, duas em Duque de Caxias, uma em São João de Meriti e uma em Mendes; Guanabara: qua:enta no Rio de Janeiro: São Paulo: quarenta em São Paulo, cinco em Campinas, três em Ribeirão Prêto, duas em Jundiai, duas em Táubaté, duas em Bauru, uma em Jacareí, uma em São José dos Campos, uma em Mogni Mirim, três em Santo André, tîes em São Bernardo do Campo, uma em Mogi Guaçu, duas em Sorocaba, duas em São Caetano do Sul, duas em Mogi das Cruzes, duas em Santo Amaro, dez em Santos, uma em Botucatu, uma em Guaratinguetá, uma em Marilia, uma em Limeira, uma em Rio Claro, uma em São Carlos, uma em Araraquara, uma em Araras, uma em Presidente Prudente, uma em Americana, duas em Piracicaba, uma em Araçatuba, uma em Franca, uma em São José do Rio Prêto e uma em Barreto; Paraná: dez em Curitiba, duas cm Ponta Grossa, duas em Londrina, uma em Apucarana, uma em Jaca:èzinho e duas em Paranaguá; Santa Catarina: três em Florianópolis, duas em Blumenau, duas em Brusque, duas em Jaraguá do Sul, uma em Lages, duas em Itajai, duas em Joinvile e duas em São Francisco do Sul; Rio Grande do Sul: de'z em Pôrto Alegre, uma em Bagé, duas em Cachoeira do Sul, duas em Caxias do Sul, duas em Santa Cruz do Sul, duas am São Leopoldo, duas em Santa Maria, t-ês no Rio Grande, duas em Livramento, duas em Uruguaiana, uma em Santo Ångelo, uma em Passo Fundo, uma em Bento Gonçalves. quatro em Pelotas e uma em Nôvo Hamburgo; Gciás: cinco em Goiânia, duas em Anápolis, uma em Dianópolis, uma em Formosa e uma em São Gabriel; Distrito Federal: dez em Brasilia; Mato Grosso: duas em Cuiabá, duas em Campo Grande; e duas em Corumbá.

Art. $8^{\circ}$ As attuais Delegacias Fiscais do Tesouro Nacional nos Estados passarão a denominar-se Delegacias Regionais das Rendas Internas (D.R.R.I.).

Pa:ágrafo único. As D.R.R.I. terão a mesma organização e atribui ções que os órgãos por elas substituidos.

Art. 9: Ficam criadas duas (2) D.R.R.I., com jurisdição e sedes respectivas no Distrito Federal e Estado da Guanabara.

Parágrafo único. Para funcionarem junto às D.R.R.I., a que se refere êste artigo, são criadas duas (2) Contadorias Seccionais.

Art. 10. As D.R.R.I. são diretamente subordinadas, administrativa e tècnicamente, à Diretoria das Rendas Internas.

Art. 11. Subordinadas às respectivas D.R.R.I., são criadas quarenta (40) Delegacias Seccionais das Rendas Internas (D.S.R.I.), nos seguintes Estados, assim distribuidas: Ceará: duas; Paraiba: uma; Pernambuco: duas; Bahia: três; Minas Gerais: nove; Espirito Santo: uma; Rio de Janeiro: duas; São Paulo: nove; Paraná: três; Santa Catarina: três; Rio Grande do Sul: guatro e Goiás: uma.

Parágrafo único. As sedes das D.S.R.I. serão localizadas, de preferência, nas cidades onde existir Delegacia Seccional do Impôsto de Renda. 
Art. 12. As D.S.R.I. terão a mesma organização e funcionamento que as D.R.R.I. a que estão subordinadas, guardadas as proporções do âmbito de ação dêsses órgãos.

Art. 13. A jurisdição das D.S.R.I. será dete:minada em ato do DiretorGeral da Fazenda Nacional, mediante proposta do Diretor das Rendas In. ternas.

Art. 14. Subordinadas às Contadorias Seccionais junto às D.R.R.1.. ș̃o criadas as seguintes Subcontadorias Seccionais, que funcionarão junto às respectivas D.S.R.I.: Ceará: duas; Paraiba: uma; Pernambuco: duas; Bahia: três; Minas Gerais: nove; Espirito Santo: uma; Rio de Janeiro: duas; São Paulo: nove; Paraná: três; Santa Catarina: três; Rio Grande do Sul: quatro e Goiás: uma.

Parágrafo único. As Subcontadorias Seccionais terão, atendido o seu âmbito de ação, a mesma o-ganização e atribuições que as Contadorias Seccionais a que estão subordinadas.

Art. 15. Fixada, pela Administração da Fazenda Nacional, a lotação dos órgãos administrativos instituídos por esta lei, o Poder Executivo proporá ao Legislativo, dentro de sessenta (60) dias, a criação dos cargos correspondentes, sem prejuizo do aproveitamento, com absoluta prioridade, do pessoal remanescente dos órgãos que foram transformados em virtude desta lei.

Art. 16. A Administração da Fazenda Nacional procederá à revisão da lotação das Recebedorias Federais em São Paulo, Estado da Guanabara e Belo Ho:izonte, tendo em vista adaptá-la, face à nova estrutura do aparelho arrecadador, prevista nesta lei, às necessidades e conveniências dos serviços dêsses órgãos.

$\S 1^{\text {? }} \mathrm{O}$ pessoal, que em virtude da revisão de que trata êste artigo, exceder da lotação dêsses órgãos, será, com absoluta preferência, aproveitado no preenchimento das vagas existentes nas D.R.R.I. e Coletorias Federais criadas por esta lei.

$\S 2^{\circ}$ E assegurado aos funcionários lotados nas Recebedorias Federais, o direito de optar, no prazo de sessenta $(60)$ dias, por sua lotação nas Coletorias Federais situadas na respectiva localidade, após transferência para nivel equivalente da classe de Auxiliar de Coletoria, mediante requerimento dirigido ao Diretor-Geral da Fazenda Nacional.

Art. 17. Dentro de sessenta (60) dias da vigência desta lei, o DiretorGeral da Fazenda Nacional expedirá as normas destinadas a estabelecer a distribuição e coordenação dos serviços, entre os órgãos subo-dinados e subordinantes, criados por esta lei.

Art. 18. A lotação numérica e nominal das Coletorias Federais será organizada pelo Serviço do Pessoal da Fazenda, com a colaboração da Diretoria das Rendas Internas, e aprovada pelo Diretor-Geral da Fazenda Na. cional, tendo em vista o indice de serviço e o volume de arrecadação da exatoria, cujo quadro funcional constará, no minimo, de um Coletor, de um Escrivão e de um Auxiliar de Coletoria.

$\S 1^{\circ}$ Quando a Coleto ia fôr provida de mais de um Coletor, a chefia dela caberá ao de nivel mais elevado; em caso de igualdade de nivel, ao mais antigo na classe, e, por fim, ao que possuir maior tempo de serviço.

$\S 22^{\circ}$ Os Coletores serão substituidos, nos seus impedimentos legais, na chefia da Coletoria, pelos Escrivães e êstes pelos Auxiliaces de Coletoria, com observância do disposto no parágrafo anterior.

Art. 19. A movimentação do pessoal lotado nas Coletorias Federais far-se-á a pedido ou "ex-officio", no interêsse da administração, mediante ato 
do Diretor-Geral da Fazenda Nacional, com a audiência da Diretoria das Rendas Internas.

Art. 20. Ficam criados, na Parte Permanente do quadro do Pessoal do Ministério da Fazenda, os seguintes cargos das classes que se mencionam, integrantes do Grupo Ocupacional AF-300:

350 (trezentos e cinqüenta) cargos de Coletor - Código AF-306:15A,

350 (t:ezentos e cinqüenta) cargos de Escrivão - Código AF-307.12A

1.400 (um mil e quatrocentos) cargos de Auxiliar de Coletoria - Có. digo $\mathrm{AF}-308-8 \mathrm{~A}$.

Art. 21. E' vedada a nomeação em caráter interino, para preenchimento de vagas referentes à série de classes de Coletor, Escrivão e Auxiliar de Coletoria.

Parágrafo único. A Direção-Geral da Fazenda Nacional diligenciará, junto ao órgão competente, para a realização periódica de concursos públicos, destinados à habilitação de candidatos ao preenchimento de vagas das classes mancionadas neste artigo, de modo a não haver claros na lotação das Coletorias Federais.

Art. 22. Para integrarem a lotação das Coletorias Federais, ficam cria. dos, na Parte Permanente do quadro do Ministério da Fazenda, 1.500 (um mil e quinhentos) cargos da classe de Servente - Código CL-104.5.

Art. 23. Pa:a preenchimento dos claros existentes ne lotação das Co. letorias Federais criadas por esta lei, terão preferência os atuais Coletores, Escrivães e Auxiliares de Coletoria, bem como o pessoal a que se refere o art. $16, \S 2^{\circ}$, atendida a legislação vigente.

$\S 1^{\circ}$ Mediante reque-imento dirigido ao Diretor-Geral da Fazenda Na. cional, por intermédio dos respectivos chefes imediatos, o funcionário solicitará sua remoção para a Coletoria Federal que preferir, podendo indicar mais de uma Coletoria, até o número de três (3), escalonadas segundo a ordem de preferência.

$\$ 2$. Se houver mais de um candidato para o mesmo claro, a escolha obedecerá ao critério indicado no $\S 1^{\circ}$ do art. 18 .

$\S 3^{\circ}$ Os chefes imediatos dos candidatos ac preenchimento dos claros a a que êste artigo se refere, darão conhecimento, por telegrama, ao Serviço do Pessoal da Fazenda, dos requerimentos de remoção que lhes foram cncaminhados.

Art. 24. O direito à peferência estabelecida no artigo anterior, prescreverá em sessenta (60) dias da data da publicação da p:esente lei.

Art. 25. O Poder Executivo proporá ao Legislativo a criação de Te. souraria na Coletoria Federal que durante vinte e quatro (24) meses consecutivos de dois (2) exercicios financeiros apresentar renda mensal igual ou superior a cinco mil $(5.000)$ vêzes o valor mensal do maior salário-minime vigente no Pais, e contar com mais de quatrocentos (400) contribuintes do Impôsto de Consumo e oitocentos $(800)$ do Impôsto de Renda

$\S 1^{\circ} \mathrm{E}^{\prime}$ extensivo à Tesouraria de que trata êste artigo, no que lhe fôr aplicável, o disposto no Decreto $\mathrm{n}^{\circ} 8.740$, de 11 de fevereiro de 1942 . alterado pelos de 12 s. 12.571 , de 15 de junho de 1943 . e 21.948 , de 14 de outubro de 1946.

$\S 2^{\circ}$ As Tesourarias que forem criadas em virtude dêste artigo ficarã sujeitas, no que lhes disser respeito, aos órgãos seccionais da Contadoria-Geral da República, sob cuja jurịsdição estiver a respectiva Coletoria.

§ 3. Para efeito dêste artigo, são considerados contribuintes do Impôsto de Consumo os fabricantes de produtos sujeitos a êsse tributo e os comer- 
ciantes atacadistas e varejistas, que nos têrmos do respectivo regulamento, estejam obrigados ao recolhimento de dito impôsto. Para o mesmo fim, consideram-se contribuintes do Impôsto de Renda as pessoas físicas ou juridicas que apresentem, no exercício, declaração de rendimentos não isenta.

Art. 26. Dentro do prazo de sessenta (60) dias, contados da data da publicação desta lei, o Poder Executivo proporá ao Legislativo a criação de Tesourarias, para integrarem as Coletorias Federais sediadas em municipios que satisfaçam as condições previstas no artigo anterior.

Art. 27. Ficam criadas, na Parte Permanente do quadro do Pessoal do Ministério da Fazenda, dezenove (19) funções gratificadas, simbolo 2-F, de Inspetor de Coletorias.

Art. 28. Para atender às despesas decorrentes desta Lei, é o Poder Executivo autorizado a abrir, pelo Ministério da Fazenda, o crédito especial de Cr\$ 10.000.000.000,00 (dez bilhões de crlizeiros), com vigência em cinco (5) exercicios consecutivos.

Parágrafo único. O crédito a que se refere êste artigo se:á automàtica. mente registrado pelo Tribunal de Contas e distribuido ao Tesouro Nacional para aplicação pela Diretoria das Rendas Internas.

Art. 29. As Agências de Ar:ecadação sediadas na cidade do Rio de Janeiro, Estado da Guanabara, e no bairro denominado Campinas, em Goiânia, Capital do Estado de Goiás, serão extintas, quando instaladas as Coletorias Federais que as substituam, das criadas por esta lei.

Art. 30. Ficam revogados os artigos 13, 15, 19, 20, 21, 22, 23, 25. $45,69,70,71,72,74$ e 79 da Lei $n^{\circ} 1.293$, de 27 de dezembro de 1950 , bem assim o artigo $3^{\circ}$ e seu parágrafo, da Lei $n^{\circ} 2.584$, de $1^{\circ}$ de setembro de 1955, e demais disposições em contrário.

\section{Justificação}

O artigo $1^{\circ}$ do presente projeto de lei, ao restabelecer o critério de pluralidade de exato:ias, já adotado, anteriormente, na estruturação do sistema arrecadador federal, e aplicável às localidades em que o indice de arrecadação seja cxpressivo, obedece aos mais sólidos e difundidoss principios estruturais dentre os quais se sobressaem o da descentralização das funções de execução; o da divisãc do trabalho e o da comodidade da clientela.

A experiência passada demonstrou, contudo, que, para se conseguir o maior rendimento possivel da aplicação do sistema de pluralidade de exatorias no aparelho arrecadador, seria necessário condicioná-lo a um prévio e criterioso zoneamento das circunsc-ições fiscais, de modo a garantir um perfeito atendimento dos respectivos núcleos populacionais, evitando-se, ao mesmo tempo, confusão na jurisdição e competência dos órgãos arrecadadores. Dai adotar-se o critério do número de habitantes e o de estabelecimentos comer. ciais e industriais existentes na localidade, aplicável à divisão das zonas fiscais, que, aliás, já era observado na legislação passada. Essse critério, inserido no artigo $2^{\circ}$ do presente projeto, combinado com $\circ$ disposto no artigo $3^{\circ}$, relativo à localização das sedes de Coletoiias, e com o estabelecido no artigo $6^{\circ} \mathrm{e}$ seu parágrafo único, relativamente à criaçãc e anexação da Coletoria, com. pleta o conjunto de condições que devem presidir a existência do órgão arrecadador, assegurando-lhe um harmônico funcionamento.

Paralelamente à implantação do sistema de multiplicidade de exatorias, visando ao descongestionamento de suas funções, segundo o p:incípio da divisão do trabalho, tida como a medida mais necessária à regularização dos serviços de arrecadação das rendas federais, coloca-se, no mesmo plano, outra medida referente à distribuição das funções inerentes aos órgãos integrantes 
do aparelho arrecadador do Ministério da Fazenda, consoante a natureza de cada um, a fim de que não haja desvios prejudiciais à economia do conjunto. Ao discriminar-se quais as espécies de tributos que devam ser arrecadados pelas exatorias subordinadas à Diretoria das Rendas Internas e quais as que - serão pelas repartições arrecadadoras dependentes da Diretoria das Rendas Aduaneiras, esta ordenação virá corrigir, de imediato, uma anomalia, que há longo tempo se observa no aparêlho arrecadador federal, no tocante às re. partições alfandegárias, segundo a qual lhes é atribuida, juntamente com a função de arrecadar os impostos de importação e taxas de serviços aduaneiros, também a de cob:ar os impostos internos, sobrecarregando-as, assim, de incum. bência estranha à sua natureza, que as desvirtua de suas verdadeiras atribuições legais, como sejam a execução dos serviços de repressão ao contrabando e sua apreensão; o policiamento fiscal dos mares territoriais, costas, rios, lagos e águas interiores, assim como das fronteiras terrestres, ancoradouros, portos, cais e docas; fiscalização de aercportos, entrepostos, armazens e trapiches alfandegados, além da arrecadação dos mencionados tributos de importação e afins. Tal disciplinamento e benéficos resultados dêle decorrentes, é o que objetiva alcançar o artigo $4 \%$ do presente projeto de lei, indicando se no art. $6^{\circ}$, completado pelo que lhe precede, dentre as novas Coletorias a serem criadas, quais as que serão instaladas em localidades, cuja arrecadação de impostos internos, até agora, vem sendo realizada por repartições aduaneiras, a fim de que sejam desobrigadas dêste mister.

Deve-se p:evenir contra a alegação dos que, por qualquer motivo ou interêsse, se opuserem a essa salutar medida, de que o retirar das repartições aduaneiras a função de arrecadar impostos internos viria causar-lhes prejuizos, não a aceitando por improcederte, porque pesadas e importantes tarefas elas têm a cumprir, dentro das atribuições que lhes são próprias, como, por exemplo, o combate ao contrabando, que, por deficiente, graves danos ocasiona ao Pais, e mesmo porque, o cumprimento da lei, que é o que se pretende conseguir com a proposição de que se trata, a ninguém pode pre. judicar.

O preconizado desdobramento dos órgão: que integram o sistema arrecadador federal, conforme o principio da descentralização das funções de exe. cução, para alcançar o seu pleno rendimento, não deve restringir-se, apenas, às exatorias pròpriamente ditas, mas estender-se até às Delegacias Fiscais do Tesouro Nacional, a que aquelas se acham subordinadas, porque também estas padecem do mesmo mal da hipertrofia, decorrente do excesso de encargos que thes são cometidos. Esses importantes órgãos fazendários, sediados nas $\mathrm{Ca}$. pitais dos Estados, são, ao mesmo tempo, órgãos de execução e de contrôle. Sob a sua responsabilidade são realizados os mais diversos e complexos serviços, dos quais enumeraremos, a título de ilustração. os seguintes:

a) Superintender e executar o serviço da despesa da União, na área de sua jurisdição;

b) Julgar, em primeira instância, os autos de infração e representação lavrados no território de sua jurisdição e, em grau de recurso, as notificaçães julgadas pelos exatores que lhes são subordinados;

c) Supervisionar, orientar, controlar e inspecionar os serviços de arrecadação a cargo das Coletorias Federais sediadas no território a elas jurisdicionado;

d) Executar os trabalhos relativos à divida ativa da União;

e) Dirigir, no âmbito de sua competência, a fiscalização do Impôsto de Consumo, do Impôsto do Sêlo nas operações bancárias, do Sêlo Penitenciário, da Garimpagem e do Comércio de Pedras Preciosas, etc.

Para se desincumbirem dessas funções, as Delegacias Fiscais realizam as mais variadas tarefas, que são executadas sempre tumultuadamente, devido, principalmente, ao acúmulo de serviços, de que se acham incumbidas. 
Há necessidade, pois, de se dividi-las em dependências seccionais, que se incumbam dos mesmos serviços, em âmbitos juridicionais menos extensos.

$\mathrm{O}$ artigo $8^{\circ}$ e seu parágrafo único e mais os artigos $9^{\circ}, 10,11.12$ e 13 tratam, respectivamente, da transformação das atuais Delegacias Fiscais em Delegacias Regionais das Rendas Internas (D.R.R.I.) e sua organização: da criação de duas D.R.R.I., para funcionarem, uma no Distrito Federal, e outra no Estado da Guanabara; da subordinação de tôdas elas à Diretoria das Rendas Internas; da criação, organização e funcionamento das Delegacias Seccionais das Rendas Internas (D.S.R.I.); e, finalmente, do modo como se determina a jurisdição destas últimas repartições, estando, assim, previstas neste Projeto de lei as condições fundamentais de existência e funcionamento desses novos órgãos fazendários.

Tratam o artigo 14 do Projeto em aprêço, e seu parágrafo único, da criação de Subcontadorias Seccionais, em número igual ao das D.S.R.I., junto às quais funcionarão, subordinadas às respectivas Contadorias Seccionais, que por sua vez funcionarão junto às D.R.R.I., ficando, desta forma, igualmente descentralizados os serviços contábeis dessas repartições, ao passo que o artigo 15, seguinte, cuida da lotação dos órgãos administrativos ora criados, dando-se preferência absoluta para o aproveitamento do pessoal oriundo dos órgãos anteriormente existentes, que foram transformados $\mathrm{cm}$ virtude da proposição de que se trata, dispositivo êste que, juntamente com o que se the segue, resolve, da maneira mais justa e econômica, o problema de pessoal dos novos órgãos criados.

Neste ponto, em que passamos a examinar o conteúdo do artigo 16 e seus parágrafos, cabe expenderem-se, em ráp:das palavras, algumas considierações em tôrno das Recebedorias Federais, para precisar-lhes a natu-eza e posição, en face do sistema arrecadador federal. Começaremos por notar que as Re. cebedorias são exatorias de grandes proporções, com a mesma finalidade que uma coletoria comum, desta diferençando apenas no tamanho, mas com atribuçõoes idênticas No entanto, sabe-se que a desmedida extensão territorial sob a jurisdição dêsses agigantados órgãos a:recadadores, que assume proporção anormal, os condena a irremediável inaptidão para bem cumprir suas finalidades, razão principal de seu comprovado funcionamento defeituoso, confirmado no mau atendimento do público contribuinte, situação considerada tanto mais grave quando se atenta para o fato de que êsses órgãos arrecadadores se acham localizados justamente nos maiores centros demográficos do Pais, como, por exemplo, a Capital de São Paulo e Cidade do Rio de Janeiro, onde o indice de arrecadação se apresenta mais elevado. Incapacitadas essas repartições arrecadadoras pelos vícios de constituição que as tornam ineptas, vêem-se as autoridades administrativas compelidas a apelar para o recurso, também vicioso, de atribuir a bancos particulares a incumbencia que só deve caber às repartiçôes arrecadadoras do Ministério da Fazenda - por lhes ser inerente - de arrecadar as rendas da União, medida esta manifestamente prejudicial, não sòmente aos legitimos interêsses da Fazenda Nacional, mas os da própria Nação, por ser profundamente anárquica e perturbadora do sistema financeiro do Pais, seja público ou privado, consoante já se fêz sentir em recente e consciencioso p:onunciamento proferido sôbre o assunto, por determinado setor fazendário, que não vem a pêlo ser aqui mencionado. Não obstante, adotou-se, no presente Projeto, a orientação de não determinar a extinção sumária dêstes órgãos, considerados, com justa razão, como os principais responsáveis pelas deficiências do atual sistema arrecadador federal, que cada vez mais se acentuam, preferindo-se, ao invés, atribuir à Administração Fazendária a incumbência de os ir adaptando, gradativamente, ao nôvo sistema instituido neste Projeto, dando-se-lhes, afinal, uma estrutura idêntica à das demais Coletorias, sendo êsse o objetivo colimado pelo artigo 16 e seus parágrafos, acima citados.

Cuida o artigo 17 da distribuição e coordenação dos serviços a serem realizados pelos órgãos subordinados e subordinantes, criados pelo Projeto 
incumbência esta atribuida à Direção-Geral da Fazenda Nacional, que terá o prazo de sessenta dias para expedir as normas respectivas, tarefa que será muito facilitada, recorrendo-se aos regimentos ora em vigor, que dispõem sôbre o funcionamento das atuais Delegacias Fiscais e Contadorias Seccionais.

Ao dispor sôbre a lotação numérica e nominal dos servidores das Coletorias Federais, o artigo 18 do Projeto propõe as seguintes modificações, destinadas a produzir benéficos resultados, no tocante à matéria, a saber:

a) colaboração da Diretoria das Rendas Internas na organização do quadro da pessoal da exatoria, cuja lotação será integrada, no minimo, por um coletor, um escrivão e um auxiliar de coletoria, a qual será fixada mediante ato da Direção-Geral da Fazenda Nacional; e

b) possibilidade de a coletoria, quando necessário, ser provida de mais de um coletor.

Presentemente, a incumbência de elaborar e controlar a lotação das exatorias federais, no tocante a coletores, escrivães e tesoureiros, é cometida, apenas, ao Serviço do Pessoal da Fazenla, a qual é fixada mediante decreto do Presidente da República. Em relação, porém, à atual classe de auxiliares de coletorias, pelo menos durante o tempo em oue esta categoria de funcionários se constituia, simplesmente, em uma série funcional de extranumerário, tal atribuição e:a reservada à Diretoria das Rendas Internas, que fixava e controlava a lotação dos auxiliares de coletoria, organizada por Estados, através do seu Serviço de Coletorias Federais, sendo que a localização dêsses servidores, nas respectivas Coletorias, se efetivava mediante ato do Delegado Fiscal, a cuja ju:isdição pertenciam.

Por ser uma das principais finalidades da Diretoria das Rendas Internas o acompanhar, pari passu, o funcionamento cotidiano das exatorias federais, em virtude de preceito regimental, nenhuma outra diretoria do Tesou - o $\mathrm{Na}$ cional está mais capacitada do que ela para decidir sôbre assuntos que dizem respeito a essas estações arrecadoras, daí o acêrto da lei ao determinar a sua participação direta na organização do quadro de pessoal das coletorias federais.

Notamos, igualmente, que, dispondo a lei que dita lotação seja fixada por ato do Diretor-Geral da Fazenda Nacional, que é a autoridade máxima que superintende os assuntos administrativos do Tesouro Nacional, ao mesmo tempo que desobriga a Presidência da República de uma atribuição administrativa secundária, garante, sem quebra de segurança, maio: presteza e flexibilidade na movimentação dessa classe de servidores, tão necessária ao bom andamento dos serviços atinentes a èste importante setor fazendário.

De outra parte, ao estabelecer que a lotação de uma coletoria se componha, no minimo, de um coleto:, um escrivão e um auxiliar, qualquer que seja a seu indice de serviço, assegura a lfi proposta, no tocante a pessoal de coletoria, condições as mais favoráveis, que hoje não se verificam, para o normal funcionamento dêsses importantes órgãos arrecadadores das rendas đa União, cuja paralisação de suas atividades, que, na maioria das vêzes, ocorre em virtude de impedimento do seu quase sempre único servidor, acarreta, invariàvelmente, graves prejuizos ao Erário público e ao contribuinte. Considera-se, por último, a vantagem de se permiti: seja a coletoria provida de mais de um coletor, porque também neste particula: não deve haver restrições à Administração em resolver casos concretos, „como o que atualmente se verifica, por exemplo, com relação às Coletorias Federais em Goiânia, Curitiba e tantas outras, em que, por circunstâncias especiais, houve necessidade de provê-las de mais de um coletor, tanto mais que o problema da chefia da repartição, que é exercida pelo coletor, em tais casos é resolvido de acôrdo com o disposto nos parágrafos $1^{\circ}$ e $2^{\circ}$ do aludido artigo $1 \mathrm{~S}$ do Projeto, completados pelo artigo seguinte.

Correspondente ao número de coletorias, cuja criação se propõe no artigo $6^{\circ}$ dèste projeto, é criado pelo artigo 20 número igual de coletores e de 
escrivães, sendo que, quanto a auxiliares de coletorias, o quadro respectivo é ampliado com mais 1.400 cargos, na razão de quatro auxiliares para cada nova coletoria. O núme:o quatro vêzes maior de cargos de auxiliar, criados por êste dispositivo, em relação aos de coletor e escrivão, se explica no fato cle que a totalidade das coletorias criadas pelo citado artigo $6^{\circ}$ se localiza em Capitais e grandes cidades do interior do Pais, havendo, por isso, necessidade de a lotação delas ser integrada por um número sat sfatório de auxiliares de coletoria.

Pelo artiggo 21 do Projeto em aprêço, proibe-se a nomeação interina de coletor, escrivão e auxiliar de coletoria. Esta medida se justifica plenamente, se considerarmos que as funções do exato: são, como na realidade o são, eminentemente especializadas, exigindo-se, destarte, dos que pretendem exercê-las, que tenham uma preparação adequada, e, ao ingressarem na carreira, demonstrem possuir, a par da instrução de nivel médio sôbre matérias básicas, como Português e Matemática, sólidos conhecimentos especializados sôbre Legislação Fazendária. Contabilidade Pública, Estatistica, noções de Direito Administrativo e Datilografia, sem o que não estarão aptos a exercer, satisfatòriamente, as funções inerentes a êsses cargos. Por essa razão, trata o parágrafo único do dispositivo em foco da realização periódica de concursos públicos para o ingresso nessas carreiras, a fim de que seja garantido o permanente preenchimento das vagas existentes, po: elementos comprovadamente habilitados, para o exercicio dessas funçว̃es.

Dispõe o artigo 22 sôbre a criação de 1.500 cargos de Servente para integrarem a lotação das Coletorias, número suficiente para atender às que tenham maior indice de serviço, já existentes ou por instalar. Idêntica disposição figura na legislação vigente, conforme se vê nos artigos 28 e 80 , da Lei $\mathrm{n}^{\circ} 1.293$, de 27 de dezembro de 1950, que determinam a admissão de serventes, para terem exercício nas coletorias federais sem que até agora, decorridos treze anos de vigência dessa lei. haja sido feita uma nomeação sequer dessa espécie de se-vidor, para as exatorias. Considera-se, no entanto, semelhante medida como imprescindivel à regularização dos serviços das coletorias, pois não é admissivel que os trabalhos próprios desta categoria funcional sejam executados pelo coletor ou pelo escrivão e mesmo pelo auxiliar de coleto-ia, sem prejudicar a boa ordem dos serviços a cargo dessas repartições arrecadadoras.

Tem em vista o artigo 23 a preferência cue se deve dar aos atuais servidcres de coletorias, no preenchimento dos claros existentes na lotação das exatorias uriadas por êste Projeto, preferência que se estende aos servidores attralmente lotados nas Recebedorias Federais, que optarem para servir nessas Coletorias, na forma prevista no $\S 2^{\circ}$ do artigo 16 . Tal prio-idade, sôbre ser justa, por procurar favorecer antigos servidores que, na maioria dos casos, vêm prestando bons serviços à administração fazendária, durante longos anos, dandc-lhes a possibilidade de ervirem em coletorias que lhes ofereçam melhores condições, principalmente por cstarem sediadas em localidades mais adiantadas, propiciando, igualmente, à Administração oportunidade de prover as novas coletorias que, na sua maioria, devem ap-esentar elevado índice de arrecadação, de servidores experimentados e eficientes. Os parágrafos que sc inserem no referido artigo 23 dispõem sôbre os requisitos a serem satisfeitos para a concorrência dos candidatos ao preenchimento dos claros existentes nessas novas exato:ias, requisitos êsses baseados em critério já adotado na legislação vigente, para casos semelhantes, cuịo direito à preferência estabelecida nesses dispositivos tem o seu prazo de prescrição fixado no artigo que se thes segue.

Referem-se o artigo 25 e seus três parágrafos à criação de tesoura-ias, para funcionarem integradas às coletorias federais, renovando, aliás, dispositivo constante na legislação em vigor. As duas principais modificações int:oduzidas na atual proposição, ciestinadas, sem dúvida, a aperfeiçoar as condições 
para a criação dêsses importantes órgãos que integram o aparelho arrecadador federal - firmadas no volume de arrecadação e $\mathrm{n}_{\mathrm{O}}$ número de contribuintes atendidos pela coletoria, em dois exercícios consecutivos - consistem, a primeira dessas modificações, na elevação do coeficiente da arrecadação mensal da exatoria, cajo montante em cruzeiros é fixado com base no valor mensal do maior salário-mínimo vigorante no País, para a garantia de uma varıação automática, em face da instabilidade monetária, a que se relaciona, intima. mente, o valor dos salários; e a outra, na definição clara e precisa, para o caso, do conceito de contribuintes do impôsto de consumo e do impôsto de renda.

No artigo 26, é dado um prazo razoável de sessenta dias para que a atłministração fazendária proceda ao levantamento das coletorias que satisfaçam às condições previstas no artigo anterior, a fim de que o Poder Exe. cutivo proponha ao Legislativo a criação de tesourarias.

A fim de que não fiquem sobrecarregados os serviços de inspeção de coleto:ias, com a criação das trezentas e cinqüenta coletorias, de que trata o artigo $7^{\circ}$ dêste Projeto, prevê o artigo 27 a criação de dezenove funções de Inspetor de Coletorias, que, somadas às oitenta e uma funções já existentes, perfazem um total de cem funções, número suficiente para atender, satisfatòriamente, aos serviços de inspeção de cêrca de duas mil e quinhentas coletorias. disseminadas por todo o território nacional, tocando uma média de vinte e cinco para cada inspetor.

O crédito especial de dez bilhões de cruzeiros, previsto no artigo 28 , foi estabelecido com base em criteriosa estimativa, a que se procedeu no Serviço de Coletorias Federais, órgão especializado da Ádministração Fazendária, calculando-se cada espécie de gasto destinado à instalação das cole* torias criadas pelo Projeto, segundo o título orçamentário próprio, assim discriminado:

\section{Custeio}

Niaterial de Consumo e de Transformação

Material Permanente ......................

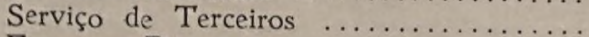

Encargos Diversos $\ldots \ldots \ldots \ldots \ldots \ldots \ldots$.

\section{Investimentos}

Equipamentos e Instalações

Soma

\section{Cr\$}

150.000 .000

1.500 .000 .000

1.500 .000 .000

2.500 .000

\subsection{0 .000 .000}

5.652 .000 .000

Quanto às despesas de instalação dos órgãos administrativos, cuja criação ot: transformação tambérn se propõe no Projeto, tais como Delegacias Regionais e Seccionais das Rendas Internas, Contadorias Seccionais e Subcontadorias Seccionais, por serem de dificil previsão, reservou-se, para satisfazê-las, a parte restante do crédito autorizado neste artigo, depois de feita a dedução da quantia acima discriminada, destinada às coletorias.

Sendo gradativa a aplicação do dito crédito, a juizo da Administração, que o utilizará, na medida das necessidacies durante o periodo de vigência, fixado em cinco exercícios financeiros consecutivos, não se imporá, pois, maiores encargos às finanças públicas, que, ao contrário, serão largamente compensadas, com incalculáveis vantagens advindas da implantação de um sistema racional de disciplinamento dos serviços de arrecadação das rendas da União, alcançado através das medidas aqui propostas.

Determina o artigo 29 a extinção das atuais agências de arrecadação existentes, três no Es:ado da Guanabara e uma em Goiânia, Capital de Goiás, 
quando forem instaladas as coletorias federais das criadas pelo Projeto, que substituirão as ditas agências. Trata-se de medida plenamente justificável, em abono da qual transcreve-se, a seguir, trechc de pronunciamento que sôbre o assunto proferiu o Serviço de Coletorias Federais:

"Cabe aqui uma observação quanto à medida que está sendo preconizada para solucionar a momentosa questão da descentralização dos serviços de arrecadação das rendas federais, qual seja a da criação de Agências de Arrecadação, medida esta que de maneira alguma atenderá ao necessário desdobramento das funções de execução, para maio eficiência désses serviços. Muito ao contrário, virá agravar o problema, visto que essas estações arrecadadoras não gozam de plena autonomia executiva e administrativa, com escrituração de seu movimento distinta da de outro órgão arrecadador, exatamente como uma coletoria comum. que arrecada as rendas, escritura-as, efetua pagamento e recolhe o produto ar-ecadado diretamente ao Banco do Brasil, à conta da União, ou por intermédio da Delegacia Fiscal, a que estiver subordinada. Ao passo que, controlada pelas Recebedorias, estas passariam a acumular as funções de ó:gão arrecadador com as de órgão controlador. à semelhança de uma Delegacia Fiscal, agra. vando, assim, a sua atual situação de sobrecarga de serviços, e comprometendo mais ainda a arrecadação, causando, portanto, maiores danos à Fazenda Nacional. A agência de arrecadação, tal como é criada, não passa, pois, de um órgão mutilado, que não tem concições de exercer as funçốes a que se destina; que nem sequer tem autonomia para pagar os seus próprios servidores, de vez que a renda por ela ar:ecadada se incorpora à da Recebedoria a que é subordinada, em cujo balancete deve figurar, a despeito de todos os inevitáveis inconvenientes que, na prática, acarreta essa circunstância, condição que a reduz a um triste apêndice de uma entidade fossilizada".

Finalmente, o artigo 30 último do Projeto, declara que ficam revogados diversos artigos da já citada Lei $n^{\circ} 1.293-50$. bem assim o artigo $3^{\circ}$ e seu parágrafo, da Lei $\mathrm{n}^{\circ} 2.584$, de $1^{\circ}$ de setembro de 1950 , e demais disposições em contrário. Êsses dispositivos que, por coerência, é determinada sua revogação, referem-se a matéria sumàriamente excluida pelo Projeto ou por êle tratada de manei:a nova, na maioria dos casos por dizerem respeito a agências de arrecaração, como será fácil verificar, coteiando-os, sendo que, dentre êles destacamos um, que merece, porém, ligeira explicação, à parte. Trata-se do artigo 25 da Lei $\mathrm{n}^{\circ} 1.293-50$, relativo ao provimento do cargo inicial da carreira de coletor, que, de acôrdo com êsse dispostivo, se efetuará mediante concurso de provas realizado entre ocupantes da carreira de escrivão de co. letorias, com mais de dois anos de efetivo exercicio no cargo. A revogação de semelhante dispostivo se impõe, porque as rest-ições por êle impostas ao provimento do cargo de coletor, só têm criado embaraços para a Administração, por dificultar o preenchimento das vagas desta carreira, sem que, por outro lado, se beneficiem os escrivães. garantindo-lhes a passagem para a carreira de coletor sem a conco-rência de elementos estranhos ao seu quadro, visto que esta faculdade já lhes é reconhecida pelo direito de transferência conferido pela mencionada Lei $n^{\circ} 1.293-50$ e pelo acesso automático assegurado pela Lei $n^{\circ} 3.780$, de 12 de julho le 1960 , que dispõe sôbre a Classificação de Cargos do Serviço Público Civil do Poder Executivo. 